\title{
Observations on the role of the private sector in the UNFCCC's loss and damage of climate change work program
}

\author{
Swenja Surminski ${ }^{*}$ \\ Grantham Research Institute on Climate Change and the \\ Environment/CCCEP, \\ London School of Economics and Political Science, \\ Houghton Street London, WC2A 2AE, UK \\ Email: s.surminski@lse.ac.uk \\ *Corresponding author

\section{Jillian Eldridge}

Department of Geography, Environment and Development Studies, Grantham Research Institute on Climate Change and the Environment/CCCEP, Birkbeck, University of London, Malet Street, London, WC1E 7HX, UK

Email: j.eldridge@geography.bbk.ac.uk

\begin{abstract}
Private sector engagement, particularly in times of public budget constraints, has become a buzz word in most policy areas, yet roles and responsibilities between public and private sectors remain indistinct. We investigate this for the United Nations Framework Convention on Climate Change (UNFCCC) work stream on addressing loss and damage (L\&D). This paper presents evidence of current engagement and expectations, from official submissions to the UNFCCC, L\&D literature, and relates this to experiences from the fields of disaster risk reduction (DRR) and climate change adaptation (CCA). Results show a degree of 'vagueness' in outlining the role of the private sector with unclear conceptual boundaries of L\&D, DRR and CCA posing challenges for stakeholders. Expectation that the private sector will support the emerging L\&D framework through knowledge, skills and resource, particularly in developed countries, is apparent. Further clarity on expectations and the ability to deliver by the private sector is required.
\end{abstract}

Keywords: loss and damage; L\&D; private sector; stakeholder engagement; climate change; insurance; UNFCCC.

Reference to this paper should be made as follows: Surminski, S. and Eldridge, J. (2015) 'Observations on the role of the private sector in the UNFCCC's loss and damage of climate change work program', Int. J. Global Warming, Vol. 8, No. 2, pp.213-230.

Biographical notes: Swenja Surminski is a Senior Research Fellow with the Grantham Research Institute on Climate Change and the Environment. Her research interests include disaster risk management and climate adaptation, with a specific focus on the role of the private sector, public-private partnerships and the insurance industry. 
Jillian Eldridge is a PhD candidate at Birkbeck, University of London and a Research Assistant at the Grantham Research Institute on Climate Change and the Environment. Her research investigates flood risk, planning policy and flood insurance.

\section{Introduction}

International efforts to respond to the challenge of managing current and future climate risks in developing countries have intensified over the last few years with a wide range of responses within the global policy areas of climate change adaptation (CCA) and disaster risk reduction (DRR). Several different tools and approaches exist, often still at the stage of piloting, although with limited evidence of their effectiveness. Key players in this area are intergovernmental organisations, as well as international leaders. Beyond this international dimension, there is clearly also a role for national governments to engage in the international policy debate within their own countries - at the regional through to local government level.

As the challenges posed by climate change are deemed too big to deal with by national governments alone (see for example, Moser, 2009), 'stakeholder engagement' has become a buzz word with the aim to bring in different perspectives and recognise roles and responsibilities within this complex policy area. Initially, international business discourse focused on mitigation and how companies could reduce their own emissions or foster technical change towards a low emission future, but there is now growing paradigm of 'engaging the private sector' for adaptation. This ranges from financial input to providing technical expertise and the potential is well versed, yet this role remains undefined particularly in relation to adaptation to climate change. Policy makers however advocate involvement of the private sector as a solution to meeting public policy especially in the current climate of constrained public budgets. But this seems to clash with the commercial realities of private sector companies, as the rules of engagement are hardly understood and public-private collaboration is often hampered by a range of barriers (Surminski and Oramas-Dorta, 2011).

This paper aims to assess the topic of 'private sector engagement' for a relatively new policy area: The concept of loss and damage (L\&D). This has been developed within the context of climate change for the UNFCCC's adaptation framework and is one of the more recent work streams of the international climate change regime. The concept gained an official status within the Cancùn Adaptation Framework (CAF), an outcome of the 16th session of the Conference of Parties (COP) in 2010. The CAF highlights the need to strengthen international cooperation and expertise to understand and reduce L\&D associated with the adverse effects of climate change (UNFCCC, 2011a). This led to the initiation of a new work program on L\&D by the subsidiary body for implementation (SBI) culminating in the establishment, most recently at COP 19 in Warsaw, of the 'Warsaw international mechanism for L\&D' (UNFCCC, 2013a). Heralded as one of the few achievements in Warsaw, this continues to bring attention to the topic.

Decisions made at COP18 and COP19; inviting action for assessment and response on L\&D from the private sector and those outside the Convention [UNFCCC, (2013a, 2013b), p.22], both indicate that certain expectations exist about what private companies could deliver. This paper explores these expectations by assessing the submissions made 
by parties and observers to the UNFCCC's L\&D work program since its inception in 2011. This paper considers the relevance of $L \& D$ to the private sector based on the assumption that there may be 'risk' and 'opportunities' arising for the private sector building the case based on three pillars: official evidence in the submissions by parties and observers including private sector representatives; the small but growing L\&D literature, including official UNFCCC reports; and experiences from the related policy areas of CCA and DRR.

This paper faces three key challenges: Firstly, there is a lack of definition of L\&D. The framing and conceptual design of L\&D continues to evolve rapidly within debate at both UNFCCC level and with climate change commentators, with a range of stakeholders displaying different understandings of terminology and concept, posing implications as to how L\&D is understood, this is outlined below. Another challenge arises from the use of the term 'private sector'. It is an extremely broad category, encompassing actors of all forms ${ }^{1}$, across various sectors and locations, and driven by a wide range of regulations and governance arrangements. This is important when discussing vulnerability, resilience and adaptive capacity and a more in depth analysis of roles would require a sectoral focus. The one unifying aspect is the goal to make a profit. For L\&D the one sector specifically referenced is insurance, due to two main reasons; the nature of insurance already lends itself to the assessment of loss, analysis of hazards and financial consequences through established modelling tools. As well as insurance being mentioned as an element for addressing financial loss as part of a wider strategy to protect development investments (Warner et al., 2010). Other sectors are expected to become more involved in the L\&D debate as knowledge and detail of the concept expand. As it is so far the only sector that has shown some direct engagement in the L\&D debate we will explore expectations and relevance in more detail below.

Finally, it is important to note that this analysis maintains a global focus on private sector engagement driven by the UNFCCC's L\&D work stream. Clearly, there are processes and initiatives at national and local level that determine private sector engagement, as well as those within companies. This paper provides some references to this, but a more detailed assessment is beyond the scope of our investigation. This final point is revisited in our concluding observations, as it could have some potential relevance for the current debate about the UNFCCC's governance approach to L\&D.

\section{The wider context: the role of the private sector in international efforts to manage climate risks}

A range of surveys and reports on the private sector's response to climate risks suggest that business views climate change both as a risk and an opportunity. The motivation of the private sector to engage can vary, drivers can be operational or strategic, a commitment to corporate social responsibility, a response to regulation, or broader stakeholder relations (PWC, 2010) - new goods and services maybe in demand, while existing business approaches may become unviable. At the same time, a range of market failures exist, creating barriers for private sector action and requiring government intervention. Some elements of climate risk management have public good character (Fankhauser et al., 2013), triggering questions about: public versus private action, incentivising versus crowding out, social protection versus free-market responses. The role of the private sector is therefore a fundamental one, deeply rooted in economic 
theory and political economy. In broad economic terms engaging the private sector is considered as an option to increase efficiency, a response to budgetary constraints and a way to unleash private sector investment and financial flows. Add to this academic perspective the political reality - expectations, trust, openness and the public perception of business, as well as the commercial realities facing private sector players and this area becomes even more complex.

It is a useful exercise to reflect on current efforts to assess roles and responsibilities of the private sector within the global spheres of CCA and DRR. Private sector engagement is a key term that appears in both the L\&D discourse and CCA and DRR literature, but there is a lack of clarity on roles and responsibilities - there seems to be an increasing focus on the potential role of organisations in the private sector as implementers of CCA policies within the climate policy discourse: The Nairobi work program of the UNFCCC on private sector engagement stresses "the unique expertise of the private sector, its capacity to innovate and produce new technologies for adaptation, and its financial leverage can form an important part of the multi-sectoral partnership that is required between governmental, private and non-governmental actors" (UNFCCC, 2012a). But despite a normative international policy position supporting their involvement very little is known about the role of the private sector in adaptation (Agrawala et al., 2011; Agrawala and Fankhauser, 2008; PWC, 2010). Initial research in this area has focused on identifying and classifying the different actors currently involved (see Agrawala et al., 2011; Berrang-Ford et al., 2011; PWC, 2010; Tompkins et al., 2010) or analysing the theoretical roles for different actors (Agrawala and Fankhauser, 2008; Berrang-Ford et al., 2011; Tompkins et al., 2010). What is still relatively unclear is the effectiveness of the private sector's activities with regards to adaptation and DRR. Most of this action would not be visible at the international level, but occur locally, nationally or at company level. In line with our global focus on the UNFCCC's L\&D work stream we can identify existing structures to facilitate engagement of the private sector on CCA and DRR at a global level:

a The UNFCCC's Adaptation Private Sector Initiative (PSI) was launched in 2011/2012, showcasing action involving private sector partners (UNFCCC, 2013c). The PSI has currently around 108 member organisations, of which most are private sector companies, but also include public/private partnerships and public bodies. Currently, there are 88 examples of adaptation action, covering 18 different economic sectors in a range of countries. Examples include developing a holistic risk management framework to support food and income security to farmers work in Ethiopia, involving Swiss Re and Oxfam America. Another example showcases work involving Allianz, who provide micro-insurance products in several countries including India and Indonesia. The approach uses innovative private sector initiatives to deliver favourable solutions for CCA for vulnerable communities. However, while pointing to activities on the ground, and contributing to awareness raising and best practice advice it is far from clear how effective these global efforts are in fostering a better adapted private sector.

b In the area of DRR, private sector engagement at the international level is facilitated by the UNISDR's Disaster Risk Reduction Private Sector Partnership (DRR-PSP) (UNISDR, 2013a), which has 50 members, covering approximately 14 different economic sectors (see Table 1). The initiative promotes public-private partnerships and advocates knowledge within the private sector in order to increase disaster 
resilience. In a statement, some of the DRR-PSP members have recently called on fellow businesses to 'build partnerships to analyse the root causes of non-resilient activity; leverage private sector expertise in construction, communications, financing, transport and contingency planning; spread knowledge about risk, prediction, forecasting and early warning; assist governments to conduct risk assessments; and help develop standards and procedures for enhancing resilience' (UNISDR, 2011). Within UNISDR, the Global Assessment Report 2013 makes private sector engagement a key theme, with UNISDR Chief Margareta Wahlström stating: "How the private sector and governments take onboard the key findings of this report will influence trillions of dollars of investment in critical infrastructure in years to come" (UNISDR, 2013b). But similar to the CCA field it is also unclear how effective these DRR mechanisms are.

Table 1 Members of the UNISDR DRR-PSP

\begin{tabular}{|c|c|c|}
\hline Economic sector & Members & $\begin{array}{l}\text { Number of } \\
\text { companies } \\
\text { in sector }\end{array}$ \\
\hline $\begin{array}{l}\text { Consultancy/management } \\
\text { systems and services }\end{array}$ & $\begin{array}{l}\text { AECOM, EUROCONSULT ANDORRA, S.A., } \\
\text { Keyfiat Sazan, Mind-Alliance Systems, Singapore } \\
\text { Business Federation, Smart Leveraging Consult, Sure } \\
\text { House Consulting Ltd., UC\&CS Globals de R.h. de C. } \\
\text { V, United Consulting Services, S.C. }\end{array}$ & 9 \\
\hline Financial & $\begin{array}{l}\text { Assessores, S.C., BJD Reinsurance Consulting, LLC, } \\
\text { Castillo Zumaya S.C., Castro Parra \& Associados, } \\
\text { Deloitte, Despacho Florez Vega y Cia S.C., Dev Bank } \\
\text { of Japan, Gerser Contadores Publicos S.C., Hernandez } \\
\text { Golvan y Cia S.C., MHPTV, Moises Solares Arenas, } \\
\text { Quinones Espejel y Asociados, S.C., Ramirez Aguirre } \\
\text { y Ga S.C, Ramirez y Jimenez Contadores Abogados y } \\
\text { Asesores, S.C., Rodrigues Zachera Y Asoc, Servicont } \\
\text { Contadores Publicos Asociados, Sociedad Auditora } \\
\text { Weis Asociados S.C. }\end{array}$ & 17 \\
\hline Insurance & Marsh S.A. & 1 \\
\hline Energy and utilities & EDP - Energias de Portugal & 1 \\
\hline Information technology & $\begin{array}{l}\text { eVigilo, Field Secure, IBM Canada, Kokusai Kogyo, } \\
\text { MASA Group, Risk Management Solutions, Unified } \\
\text { Messaging Systems AS, WeatherRisk }\end{array}$ & 8 \\
\hline Engineering & $\begin{array}{l}\text { ISG Illumination Systems, Llc., } \\
\text { Weir-Jones Engineering Consultants Ltd. }\end{array}$ & 2 \\
\hline Education/advocacy & Small Equity Initiative & 1 \\
\hline Construction/infrastructure & $\begin{array}{l}\text { Concrete Joint Sustainability Initiative, Hindustan } \\
\text { Construction Co. Ltd., Portland Cement Association, } \\
\text { Titan America }\end{array}$ & 4 \\
\hline Water management/systems & Wellthy & 1 \\
\hline Safety and health & Consejo Colombiano de Seguridad & 1 \\
\hline Corporate responsibility & Forum Empresa, SM Prime Holdings, Inc. & 2 \\
\hline Healthcare & Glaxo Smith Kline & 1 \\
\hline Marine exploration & In Ovations Holdings & 1 \\
\hline Tourism & Pacific Asia Travel Association & 1 \\
\hline
\end{tabular}

Source: UNISDR (2013a) 
Over the past several decades, the private sector in developing countries has steadily gained in economic importance relative to the public sector (World Bank, 2012, 2013). This has triggered some more regionally focused initiatives, such as the private sector initiative for Africa (UNISDR, 2013c). Such engagement generally tends to be with multinational companies, who seem more likely to have the capacity to engage with global policy makers. Engagement of domestic or small to medium sized private sector companies is more likely to occur at national or local level - for example, Bangladesh, which has setup a National Plan for Disaster Management 2010-2015 that determines where responsibilities should lie among the government, NGOs and the private sector (UNFCCC, 2012b).

\section{The concept of $L \& D$ within the UNFCCC}

The concept of climate change L\&D officially entered the UNFCCC discussions in 2007 [UNFCCC, 2008; Para 1(c)(iii)], with the UNFCCC providing a baseline, but leaving room for interpretation (UNFCCC, 2012c) and providing no clear definition of $L \& D$. The CAF states that approaches for L\&D should consider climatic impacts 'including sea level rise, increasing temperatures, ocean acidification, glacial retreat and related impacts, salinisation, land and forest degradation, loss of biodiversity and desertification' (UNFCCC, 2011a). A recent UNFCCC-commissioned literature review on L\&D approaches (UNFCCC, 2012b) uses the following working definition of L\&D: "the actual and/or potential manifestation of impacts associated with climate change in developing countries that negatively affect human and natural systems". It differentiates between 'loss' (negative impacts in relation to which reparation or restoration is impossible, such as loss of freshwater resources) and 'damage' (negative impacts in relation to which reparation or restoration is possible, such as windstorm damage to the roof of a building, or damage to a coastal mangrove forest as a result of coastal surges) (UNFCCC, 2012b), further analysis of these terms can be found in Surminski et al. (2012). Other recent studies link L\&D more explicitly to adaptation limits and constraints, and see L\&D as adverse effects of climatic stressors that occur despite actors' attempts to adapt (Huq et al., 2013; Preston et al., 2013; Warner and van der Geest, 2013).

Overall, we notice two different dimensions when framing $L \& D$ of climate change: First, the technical concept, which looks at tools and processes to assess and manage the risk of L\&D. And second, the political dimension of the negotiations, which considers institutional mechanisms to deal with $\mathrm{L} \& \mathrm{D}$, where requests for funding, compensation and the concept of equity across the international community play a role (Warner et al., 2010). Conceptually L\&D is closely linked to the CCA and DRR - particularly in the context of the technical aspects. With boundaries and linkages still subject to debate: Some observers consider L\&D as a predominantly political construct, with a focus on compensation aimed at transferring funds to those experiencing climate change L\&Ds (Hyvarinen, 2012). Others see it as a more targeted approach of dealing with negative climate change impacts, embedded in the climate adaptation methodology or as an approach for dealing with residual risks beyond mitigation and adaptation (Kreft, 2012). For the UNFCCC context, the most pragmatic view of L\&D would be to consider the current gaps in existing structures and policies for CCA and DRR and then reflect how an international mechanism may be created to address these gaps. While a further discussion of these conceptual aspects is beyond the scope of the paper, it is nevertheless important 
to refer to it, as it creates certain challenges for exploring the relevance of the concept for the private sector: How can L\&D be explained to the private sector? What are the elements that might be relevant for certain sectors? And what is 'new' about L\&D, particularly when considering existing efforts in CCA and DRR?

To gain a better understanding of L\&D in the UNFCCC context a look at the three thematic areas agreed under the UNFCCC's (2011b) L\&D work program in 2011 is helpful:

1 Assessing the risk of L\&D associated with the adverse effects of climate change and the current knowledge on the same.

2 A range of approaches to address $L \& D$ associated with the adverse effects of climate change, including impacts related to extreme weather events and slow onset events, taking into consideration experience at all levels.

3 The role of the convention in enhancing the implementation of approaches to address L\&D associated with the adverse effects of climate change.

This categorisation offers some guidance on the role of the private sector in L\&D from climate change, revealing two dimensions of private sector relevance. Firstly, the 'risk' to private sector companies related to extreme weather events and slow onset events. This could be either direct through climate hazards or indirect through policy responses and possible regulation triggered by the UNFCCC's L\&D work stream. The second dimension is the prospect of providing tools and services for assessing and dealing with L\&D. Both aspects will be explored below in terms of expectations and relevance to the private sector.

\section{Relevance of $L \& D$ for the private sector?}

From a private sector point of view, the conceptual separation of L\&D, CCA, and DRR might appear a highly theoretical and academic exercise, with limited relevance. Instead of indulging in this conceptual debate, we suggest using the following pragmatic 'L\&D' characterisation:

- Geographical: "developing countries that are particularly vulnerable to the adverse effects of climate change" (UNFCCC, 2008).

- Hazard: "the adverse effects of climate change, including impacts related to extreme weather events and slow onset events" (UNFCCC, 2011b).

- Temporal: "the actual and/or potential manifestation of impacts" (UNFCCC, 2012b).

- Institutional: facilitated through UNFCCC: This sets the boundary of the assessment of private sector relevance in terms of risk and opportunities.

\subsection{Risks for the private sector arising from $L \& D$}

When looking at particular stakeholders, localities or sectors it is extremely difficult to determine the risk of current and future L\&D: How might the products and services of a 
private company, such as a hotel in the Maldives, be impacted by L\&D? Within DRR and CCA literature, there are a wide range of approaches on how to assess the potential of L\&D. This was explored by two recent UNFCCC reports (UNFCCC, 2012b, 2012c), which highlight technical challenges for addressing L\&D for economic sectors, such as the difficulties of quantifying hazard and vulnerability, estimation of climate-induced losses, and the consideration of direct and indirect losses, including non-monetary losses. All these aspects have to cope with data constraints and uncertainty, for both climate science, but also for the socio-economic trends, which could potentially lead to inactivity if not addressed properly. In many developing countries, the potential to assess loss data is often very limited with government asset databases and sectoral disaster loss data unavailable or limited in scope (Mechler et al., 2009).

As the data needs and data availability differ from sector to sector and across geographical scales, a patch-work of risk assessments and loss scenarios exist, see for example, Caribsave (2013), and sectoral losses in several localities have been quantified and assessed, using modelling with specific application to L\&D (UNDP, 2010). However, downscaling and extrapolating the sectoral data can limit the applicability of the information, as seen in the case of integrated assessment models (IAMs) (UNFCCC, 2012c). The IPCC's (2012) SREX report provides the current scientific knowledge on this and gives examples of economic sectors and their potential exposure to climate risks [IPCC, (2012), pp.16 and 235], highlighting gaps in the assessment of indirect disaster impacts on social and economic systems.

Understanding risks is one aspect, but more importantly for the private sector might be the consideration of how to deal with L\&D. For Thematic area II of the L\&D work program, which focuses on potential responses to L\&D, the UNFCCC (2012b) assessed the applicability of current CCA and DRR practices. Investigating risk reduction, transfer and retention, there are a range of examples relevant for dealing with $L \& D$, but mainly in the context of extreme events, not for slow onset events. While this has not specifically been explored for the private sector, some of the examples may be relevant and applicable.

Alongside these direct impacts there is also a dimension of political risk - decisions made under the UNFCCC's work stream that could have implications for the private sector, for example; introduction of new mechanisms and regulations or changes in public funding priorities. At UNFCCC level, it is thematic area III, which explores the role of the Convention that could trigger these implications. The one area where this has already emerged is insurance, specifically highlighted in the CAF [UNFCCC, 2011a; Para. 28(a) and (b)]; asking how insurance mechanisms could be utilised to increase climate resilience in the most vulnerable countries, and how private insurers could be engaged in reducing climate risks. Any decision on these mechanisms could have an impact on the insurance industry, for example, through mandating the development of insurance pools.

There are also potential legal implications, for example, would a new L\&D mechanism provide compensation for L\&D? The private sector in developing countries could potentially receive some of those pay outs, with a dimension of liability arising for companies in developed countries. This debate remains highly speculative and also faces the challenges of determining climate change attribution. Nevertheless, there could be significant implications for the private sector (Verheyen, 2012). 


\subsection{Potential for private sector to support $L \& D$ assessment and responses}

While businesses, particularly in developing countries, are likely to see L\&D negatively impacting their business operations, there is also the potential to develop business opportunities arising from the need to respond to L\&D. Thematic areas I and II indicate a potential for the private sector to offer relevant expertise, skills and knowledge in assessing and managing risks and literature offers reference to insurance, risk modelling, private infrastructure provision (UNFCCC, 2012c) and legal services (Freier et al., 2012). Most of the private sector skills and knowledge are based on efforts to manage risks from severe weather events such as insurance, modelling (see for example, CAPRA, 2012; PCRAFI, 2012) and reconstruction, there remains, however, limited evidence of input on slow-onset events (Ranger et al., 2011).

The commercial viability of these private sector activities remains unclear. In the case of insurance, it is apparent that many projects are still at a piloting stage and subject to significant funding from donors or the public sector (Surminski and Oramas-Dorta, 2011). We will now explore how these two aspects (risks and potential) are considered in the current debate on L\&D within the UNFCCC.

\section{Evidence from submissions to the UNFCCC's L\&D work program}

Since its inception in 2011, the UNFCCC work program on L\&D has conducted several 'calls for submission', asking parties and observers for input on specific questions related to the work program:

- On 'possible elements to be included in the recommendations on L\&D' (Decision 7/CP.17, paragraph 9) (Deadline 17 September 2012) See also FCCC/SBI/2012/MISC.14.

- On what to consider under the three thematic areas of the work program (deadline 15 August 2011) see also FCCC/SBI/2011/MISC.8 and FCCC/SBI/2011/MISC.8/Add.1.

- On 'views and information on elements to be included in the work program on L\&D' (deadline 21 February 2011) see also FCCC/SBI/2011/MISC.1).

These calls give parties, observers and also 'non-admitted' organisations the opportunity to lay out their views on thematic issues, institutional questions, governance arrangements and suggestions on how to take the L\&D work program forward.

\subsection{Member responses to the UNFCCC on $L \& D$}

As of April 2013, the total number of submissions to the UNFCCC in response to these three calls stands at 72 . Of those, $28(38.8 \%)$ make explicit reference to the private sector. $^{2}$ All references call for the UNFCCC to facilitate greater engagement with the private sector in climate risk management. Norway (2011) outlines the "broad participation from stakeholders (...including the) private sector would be crucial to a 
good outcome of the work programme", while Gambia (2011) asks "to seek (private sector) contribution for a successful mechanism to address L\&D in LDCs" - but explicit detail of what this 'contribution' means remains lacking. This call is mirrored by the submission from non-parties, such as observers and non-admitted organisations. The World Health Organization, International Labour Organization, and UNISDR all reference this in a general context. However, while these submissions point to a clear deficit in integrating the private sector, they do not provide much detail on the expectations that come with it.

The US is more specific in explaining the aim of this engagement: "increase collaboration with the private sector (...) to achieve effective and comprehensive risk management. (...) We should also prioritise the development of strategies that leverage private sector resources and create market-based mechanisms that are not overly reliant on public sector budgets, and that are sustainable in the long term" (United States of America, 2011).

The only reference to the risks of L\&D for the private sector comes from Gambia, referencing the need to provide the private sector in LDCs with tools and information to help them respond to the risk of L\&D. The submission specifically mentions "climate services for users in both the public and private sector in LDCs and other vulnerable countries, (... including the) strengthening of meteorological services in developing countries to facilitate free sharing of data and information" (Gambia, 2012).

\subsection{The role of insurance in $L \& D$}

Overall, we establish a large degree of vagueness in terms of what role the private sector could play in the context of L\&D. While the UNFCCC is tasked with further facilitation of private sector engagement, it is not clear what form or shape this could take. Details on how this engagement could play out in the submissions from parties and non-parties is only referenced to in the context of one sector: insurance. This is not surprising as insurance as a mechanism of risk transfer is mentioned in the official UNFCCC documents as one area for consideration in response to L\&D (UNFCCC, 2012b). For our analysis, we need to make one important differentiation: referencing insurance as an 'instrument or mechanism' is very common across submissions and broader L\&D literature (see Kreft, 2012), but this often does not reflect on who could provide this service, e.g., public sector versus private sector provision. Examples include the call for an assessment of existing and potential insurance mechanisms, but do not specifically distinguish between public and private roles (New Zealand, 2011; Switzerland, 2011). Others point to the need to develop "potential insurance scheme(s) in particular through the private sector involvement" (Indonesia, 2011) or call for the identification of "gateways between public (individual solutions, governmental systems) and private sector (insurance)" (DKKV, 2011). Gambia (2011) specifically mentions 'insurance companies' in addition to general 'private sector' in the context of facilitating engagement and when seeking contributions to solutions under L\&D.

\subsubsection{Private sector insurance solutions and their potential}

Nauru (2012) (on behalf of AOSIS) points to the current lack of private sector solutions for insurance in low-income countries stating that they "will not be forthcoming for the benefit of SIDS and LDCs without intervention at the international level". Others warn 
that "market based for-profit insurances are unlikely to be a feasible instrument to address poor peoples' needs in developing countries - even microinsurances might not be able to adequately meet up with community needs" (BFdW, 2011). While stating that "insurance based solutions can help to address $L \& D$ as promising proposals like the ones made by the Munich Re Climate Insurance Initiative or AOSIS indicate". BfdW suggests further assessment of how to "establish innovative mechanisms for risk transfer and risk sharing', suggesting that "insurance schemes are not a 'stand alone' solution and need to be accompanied by other instruments of equal importance" (BfdW, 2011).

The US on the other hand warns that there is a risk of "crowding out private insurance providers if an international insurance pool with fully subsidised premiums' is established. The US submission clearly champions the involvement of private insurers, which are "likely to be more nimble and capable of rapid response than a global insurance facility under the UNFCCC'. The submission refers to a range of examples of existing private insurance involvement in developing products in low-income countries, and notes that 'in many cases, risk reduction and preparedness can be the least-cost option; for the most extreme and infrequent events, however, insurance often makes more sense. This area of inquiry can benefit from the expertise of private insurers and financial sector experts'. This submission also points to a need to 'pinpoint barriers to implementation and private sector participation'. More specifically, the submission suggests the "creation of a template that could be applied in various countries and regions to assess readiness for market-based insurance schemes, for those who decide that insurance is worth pursuing as part of their risk management strategy (...) and to reduce barriers to private sector entry" (United States of America, 2011).

The submission from the Grantham Research Institute (Ranger et al., 2011) raises several important points in this context that would require analysis when exploring the use of insurance for L\&D. Namely defining the role of private and public sector insurance and reinsurance providers and how initiatives can be designed and delivered, with reference to leveraging of private finance and expertise and fostering private sector growth in least developed countries (LDCs). The potential risks are also questioned; how to manage residual risks, avoid moral hazard and 'How can initiatives be designed to avoid crowding out the private sector?' (Ranger et al., 2011). With regards to the role of the UNFCCC we can identify three themes: a call for assessment of the applicability of insurance mechanisms and the role of the private sector, the need for support where private sector involvement may be lacking, and the warning of crowding out existing or emerging private sector solutions.

\subsubsection{The private insurance sector response to climate risk management and $L \& D$}

How the private sector may respond to these calls is exemplified in two submissions from organisations that have been setup by the insurance industry (ClimateWise and MCII), and one submission from the financial sector engagement platform of the United Nations Environment Programme (UNEPFI) that includes a range of private insurance companies. All three groups are examples of how insurance companies have tried to institutionalise their dialogue with policy makers in the area of climate risk management:

- ClimateWise, the industry-led climate initiative launched in 2008, points to the need for 'public-private partnerships' in order to exhaust 'what is possible in building 
resilience to climate change impacts'. Referring to pilot projects and initiatives where its members are engaged and where national governments have joined with other organisations such as private (re)insurers, to deliver new climate risk management and insurance partnerships. The submission suggests that there are lessons to be learned from these examples and offers this type of knowledge input as a 'practical contribution(s) from the insurance industry' (ClimateWise, 2011).

- The UNEP Finance Initiative (UNEPFI) describes itself as 'the largest and oldest public-private partnership between the United Nations and the financial service sector' and aims to 'facilitate industry dialogue on L\&D and provide substantive input to the UNFCCC process and the SBI L\&D work program'. The submission calls for a dialogue with policy makers to promote the mobilisation of expertise and capacity within the insurance industry for risk management and transfer and 'to reduce climate risks and build climate-resilient communities'. More specifically UNEPFI states 'the UNFCCC community and the insurance industry should have a clear understanding of each other's scope, operations, needs and practices' and references a range of guiding principles for this, including 'Private sector involvement'. The submission calls for further research on how to better insurance industry involvement in vulnerable countries through public private partnership models and facilitation of policy, regulatory and legal frameworks (UNEP, 2011).

- The Munich Climate Insurance Initiative (MCII), setup in April 2005 is particularly active in the UNFCCC discussions about L\&D and describes this work program as an 'unparalleled platform' for collaboration between the broad range of experts and decision makers across DRR and CCA, including the private sector. The MCII submissions call attention to the use of insurance as a tool supported by both the private and public sectors, using best practice to overcome challenges such as efficiency, affordability, including design features to avoid moral hazard and encourage risk reduction in low-income countries. Such a partnership could "offer the market sustainability of private sector approaches, and the flexibility and innovation of public sector approaches (and that) subsidiarity means that each partner will have clearly defined, distinct roles to play." Referencing experience with pilots and established approaches in developed countries, MCII specially suggest 'light governance structures for risk pools' and the establishment of 'a fund of last resort' to facilitate a greater involvement of the private insurance sector (MCII, 2011). One particular aspect in this submission that is likely to become the core of the debate about the role of the UNFCCC in facilitating private sector engagement is: Are policy makers prepared to use adaptation financing as a way to financially incentivise private companies? The MCII submission outlines how this 'appetite of policy makers' could be raised in the case of insurance-fundamental when exploring how to structure a $L \& D$ mechanism and how to engage the private sector.

The submissions hint at different degrees of 'enthusiasm' for private market solutions from policy makers, and some cautious support from the few private sector representatives that have been engaged in the debate so far. In conclusion, there remain many questions as to the role that private sector actors may play when exploring the use of insurance for L\&D particularly in relation to the 'public versus private' context. 


\section{Concluding observations}

We conclude with a range of observations highlighting the current debate, indicating gaps and pointing to the future direction of policy and research:

- The submissions show a degree of 'vagueness' when it comes to outlining the role the private sector could play in the context of L\&D and how this could be supported by the UNFCCC. The majority of official submissions do not consider the private sector at all, while those that do refer to it mostly in general terms as a stakeholder that needs to be consulted, involved or 'engaged'. Insurance is the only area where this has been explored in greater detail.

- From the submissions, we notice that private sector engagement is mainly seen in the context of utilising private sector expertise based in developed countries, rather than assessing current and future impacts on the growing private sector in developing countries, or exploring the potential for fostering growth of domestic industries. Considering the longer-term nature of $L \& D$ it would be important to establish how these dynamics would work in decades to come, incorporating private sector growth and other trends into this outlook.

- There is evidence that the question of private sector engagement has been mainly focused on the impact of extreme events. Suggestions about addressing slow onsets as well as estimating risks arising from slow onsets are very limited. The potential for large-scale disruption brought on by slow onset climate change hazards will require significant coordination of international trade and investment flows. Incentivising action in the private sector and marshalling the capital it has to offer is another essential feature of a concerted approach to addressing $L \& D$ from slow impact climate change hazards (Siegele, 2012).

- The topic of private sector engagement in an area such as $L \& D$ is embedded in the wider discourse about roles and responsibilities of public and private sector. The submissions and the debate on insurance show this in more detail: on one side the aim to improve efficiency by involving the private sector, on the other the concern about potentially going too far in terms of private market solutions that may not work in the context of most vulnerable countries. These questions are not unique to L\&D, but they should be considered when designing any new mechanisms to deal with L\&D at the international level.

- As seen in the related fields of DRR and CCA, there are already international efforts under way to promote private sector actions in developing countries. A closer look reveals that this engagement is mostly in terms of larger businesses operating at a global level, which are linked to global business networks and private sector platforms. For the L\&D discourse it would be important to explore to what extent these engagement models could be used and what the lessons learned are - especially for small and medium size enterprises. This could be particularly important for the risk aspects, understanding impacts and developing response strategies.

- The lack of definition and the unclear conceptual boundaries can create confusion amongst stakeholders such as the private sector. How to determine if something is adaptation, disaster risk reduction or L\&D management? While these conceptual 
aspects are important for the future policy direction and possibly the allocation of funding streams, for private sector actors it does not necessarily matter if their risks and opportunities are considered under CCA, DRR or L\&D, although policy implications and possible regulatory response might differ across these areas.

- Finally, an area that would require further research is the effectiveness of private sector engagement. While there are a range of case studies and illustrative examples in the CCA and DRR areas, no comprehensive measure exists to calculate the impact, particularly in terms of increased resilience. Have the initiatives highlighted under the UNFCCC adaptation initiative led to increased resilience? Is this more effective than regulation? And what is the scope for utilising these engagement models for L\&D?

Reflecting on the current debate about L\&D and the ongoing efforts within UNFCCC to develop international mechanisms in response to L\&D this paper provides some pointers: prioritising funds and policies is subject to debate on where the need is greatest and how best to achieve economic efficiency and equitable outcomes. Creating greater clarity on expectations of and the ability to deliver by the private sector will be important - this may possibly be the most important area for UNFCCC to focus on when aiming for private sector engagement.

\section{Acknowledgements}

The authors would like to acknowledge the financial support of the Grantham Foundation for the Protection of the Environment, as well as the Centre for Climate Change Economics and Policy, which is funded by the UK's Economic and Social Research Council and by Munich Re.

\section{References}

Agrawala, S. and Fankhauser, S. (2008) Economic Aspects of Adaptation to Climate Change: Costs, Benefits and Policy Instruments, OECD, Paris, France.

Agrawala, S., Carraro, M., Kingsmill, N., Lanzi, E., Mullan, M. and Prudent-Richard, G. (2011) Private Sector Engagement in Adaptation to Climate Change: Approaches to Managing Climate Risks, OECD, OECD Environment Working Papers 39.

Berrang-Ford, L., Ford, J.D. and Paterson, J. (2011) 'Are we adapting to climate change?', Global Environmental Change, Vol. 21, No. 1, pp.25-33.

BfdW (2011) Submission by Brot für die Welt (Bread for the World, Germany), EED (Church Development Service, Germany) and DanChurchAid, (Denmark) [online] http://unfccc.int/resource/docs/2011/smsn/ngo/246.pdf (accessed 30 March 2013).

CAPRA (2012) CAPRA Probabilistic Risk Assessment Program [online] http://www.ecapra.org/community (accessed 26 March 2013).

Caribsave (2013) The CARIBSAVE Partnership: Protecting and Enhancing the Livelihoods, Environments and Economies of the Caribbean Basin [online] http://www.caribsave.org/ (accessed 26 March 2013).

ClimateWise (2011) Submission by ClimateWise - The Global Collaboration of Leading Insurers Focused on Reducing the Risks of Climate Change [online] http://unfccc.int/resource/docs/2011/smsn/ngo/249.pdf (accessed 30 March 2013). 
DKKV (2011) Submission by the German Committee for Disaster Reduction (DKKV) [online] http://unfccc.int/resource/docs/2011/smsn/ngo/250.pdf (accessed 30 March 2013).

Fankhauser, S., Ranger, N., Colmer, J., Fisher, S., Surminski, S., Stainforth, D. and Williamson, A. (2013) An Independent National Adaptation Programme for England, Policy brief, Grantham Research Institute on Climate Change \& Environment, London, UK.

Freier, C., Guy, L., Hyvarinen, J., Mair, C. and Wilson, S. (2012) 'In preparation for Doha: defining 'legal instrument'; the 2013-2015 review; and the second commitment period under the Kyoto Protocol', Foundation for International Environmental Law and Development [online] http://www.field.org.uk/files/field_doha_negotiations_paper_august_2012.pdf (accessed 26 March 2013).

Gambia (2011) Loss and Damage: Submission by Gambia on behalf of the Least developed Countries Group [online] http://unfccc.int/files/documentation/submissions_from_parties/ application/pdf/gambia_ldcs.pdf (accessed 30 March 2013).

Gambia (2012) Submission by the Gambia on behalf of the Least Developed Countries Group on Loss and Damage [online] http://unfccc.int/files/adaptation/application/pdf/submission by_the_gambia_on_behalf_of_the_least_developed_countries_on_loss_and_damage.p $\overline{\mathrm{df}}$ (accessed 30 March 2013).

Huq, S., Roberts, E. and Fenton, A. (2013) 'Loss and damage', Nature Climate Change, Vol. 3, No. 11, pp.947-949.

Hyvarinen, J. (2012) 'Loss and damage caused by climate change, legal strategies for vulnerable countries', Foundation for international Environmental Law and Development [online] http://www.field.org.uk/files/field_loss_damage_legal_strategies_oct_12.pdf (accessed 26 March 2013).

Indonesia (2011) Proposal by the Government of Indonesia on Possible Elements of the Work Programme to Consider Approaches to Address Loss and Damage Associated with Climate Change Impacts in Developing Countries [online] http://unfccc.int/files/adaptation/ cancun_adaptation_framework/application/pdf/indonesia_22_february_2011.pdf (accessed 30 March 2013).

IPCC (2012) 'Managing the risks of extreme events and disasters to advance climate change adaptation', in Field, C.B., Barros, V., Stocker, T.F., Qin, D., Dokken, D.J., Ebi, K.L., Mastrandrea, M.D., Mach, K.J., Plattner, G.K., Allen, S.K., Tignor, M. and Midgley, P.M. (Eds.): A Special Report of Working Groups I and II of the Intergovernmental Panel on Climate Change, Cambridge University Press, Cambridge, UK, and New York, NY, USA.

Kreft, S. (2012) Loss \& Damage - Overview and Summary of Party Submissions on the Role of the Convention, Loss and Damage in Vulnerable Countries Initiative [online] http://www.loss-and-damage.net/download/6868.pdf (accessed 26 March 2013).

Munich Climate Insurance Initiative (MCII) (2011) Submission by the Munich Climate Insurance Initiative (MCII) SBI Work Programme on Loss and Damage: Ideas for Work Streams, Areas of Discussion, and Milestones up to and beyond COP18 [online] http://unfecc.int/resource/docs/2011/smsn/ngo/252.pdf (accessed 30 March 2013).

Mechler, R., Hochrainer, S., Kull, D., Khan, F., Patnaik, U. and Linnerooth-Bayer, J. (2009) Increasing Resilience to Extreme Events Options, IIASA, Laxenburg, Austria [online] http://webarchive.iiasa.ac.at/Admin/PUB/Documents/XO-09-076.pdf (accessed 12 February 2012).

Moser, S. (2009) 'Whether our levers are long enough and the fulcrum strong? Exploring the soft underbelly of adaptation decisions and actions', in Adger, W.N., Lorenzoni, I. and O'Brien, K (Eds.): Adapting to Climate Change: Thresholds, Values, Governance, pp.313-334, Cambridge University Press, Cambridge. 
Nauru (2012) 'Subsidiary body on implementation (SBI) submission of Nauru on behalf of the alliance of small island states views and information on elements to be included in the recommendations on loss and damage in accordance with decision 1/CP.16' [online] http://unfccc.int/files/documentation/submissions_from_parties/application/pdf/aosis_ submission_on_loss_and_damage_submission_2_october_2012.pdf (accessed 30 March 2013 ).

New Zealand (2011) 'Submission to the ad hoc working group on long-term cooperative action under the convention paragraphs 25-28: work programme to consider approaches to address loss and damage associated with adverse climate change impacts in developing countries' [online] http://unfecc.int/files/adaptation/cancun_adaptation_framework/application/pdf/ new_zealand_21_february_2011.pdf (accessed 30 March 2013).

Norway (2011) 'Submission on approaches to enhance adaptive capacity in developing countries that are particularly vulnerable to the adverse effects of climate change when addressing loss and damage associated with climate change impacts' [online] http://unfccc.int/files/ documentation/submissions_from_parties/application/pdf/norway_loss_and_damage.pdf (accessed 30 March 2013).

PCRAFI (2012) Pacific Catastrophe Risk Assessment and Financing Initiative [online] http://web.worldbank.org/WBSITE/EXTERNAL/COUNTRIES/EASTASIAPACIFICEXT/E XTEAPREGTOPRRDEV/0,, contentMDK:22739959 pagePK:34004173 piPK:34003707 the SitePK:573964,00.html (accessed 26 March 2013).

Preston, B.L., Dow, K. and Berkhout, F. (2013) 'The climate adaptation frontier', Sustainability, Vol. 5, No. 3, pp.1011-1035.

PWC (2010) Business Leadership on Climate Change Adaptation: Encouraging Engagement and Action, PricewaterhouseCoopers LLP, London, UK [online] http://www.ukmediacentre.pwc.com/imagelibrary/downloadMedia.ashx?MediaDetailsID= 1837 (accessed 29 March 2013).

Ranger, N., Surminski, S. and Silver, N. (2011) Open Questions about how to Address 'Loss and Damage' from Climate Change in the Most Vulnerable Countries: A Response to the Cancun Adaptation Framework, Policy paper, Centre for Climate Change Economics and Policy Grantham Research Institute on Climate Change and the Environment, London [online] http://www.cccep.ac.uk/Publications/Policy/docs/PP_Cancun-Adaptation-Frameworkresponse.pdf (accessed 26 March 2013).

Siegele, L. (2012) Loss \& Damage: The Theme of Slow Onset Impact (Advance Version) [online] https://germanwatch.org/fr/download/6674.pdf (accessed 26 March 2013).

Surminski, S. and Oramas-Dorta, D. (2011) Building Effective and Sustainable Risk Transfer Initiatives in Low- and Middle-income Economies: What can we Learn from Existing insurance Schemes?, Policy paper, Centre for Climate Change Economics and Policy Grantham Research Institute on Climate Change and the Environment, London [online] http://www2.lse.ac.uk/GranthamInstitute/publications/Policy/docs/PP_sustainable-risktransfer-initiatives.pdf (accessed 28 March 2013).

Surminski, S., Lopez, A., Birkmann, J. and Welle, T. (2012) Current Knowledge on Relevant Methodologies and Data Requirements as well as Lessons Learned and Gaps Identified at Different Levels, in Assessing the Risk of Loss and Damage Associated with the Adverse Effects of Climate Change, Technical paper, FCCC/TP/2012/1, United Nations Framework Convention on Climate Change, Bonn, Germany.

Switzerland (2011) Views and Information on Elements to be included in the Work Programme on Loss and Damage AWG-LCA 14 [online]

http://unfccc.int/files/adaptation/cancun_adaptation_framework/application/pdf/switzerland 21_february_2011.pdf (accessed 30 March 2013).

Tompkins, E.L., Adger, W.N., Boyd, E., Nicholson-Cole, S., Weatherhead, K. and Arnell, N. (2010) 'Observed adaptation to climate change: UK evidence of transition to a well-adapting society', Global Environmental Change, Vol. 20, No. 4, pp.627-635. 
UNDP (2010) Modelling the Transformational Impacts and Costs of Sea Level Rise in the Caribbean [online] http://www.caribsave.org/assets/files/SeaLvlRise-UNDPCARIBSAVESummDoc2010.pdf (accessed on 27 March 2013).

UNEP (2011) The United Nations Framework Convention on Climate Change Work Programme on loss and damage Input from the United Nations Environment Programme and the United Nations Environment Programme Finance Initiative [online] $\mathrm{http}: / / \mathrm{unfccc}$.int/resource/docs/2011/smsn/igo/110.pdf (accessed 30 March 2013).

UNFCCC (2008) Report of the Conference of the Parties on its Thirteenth Session, held in Bali from 3 to 15 December 2007, Conference of Parties decision paper, FCCC/CP/2007/6/Add.1, UNFCCC, Bonn [online] http://unfccc.int/resource/docs/2007/cop13/eng/06a01.pdf (accessed 23 January 2013).

UNFCCC (2011a) Report of the Conference of the Parties on its Sixteenth Session, held in Cancun from 29 November to 10 December 2010, Conference of Parties decision paper, FCCC/CP/2010/7/Add.1, UNFCCC, Bonn [online] $\mathrm{http} / /$ unfccc.int/resource/docs/2010/cop16/eng/07a01.pdf (accessed on 23 January 2013).

UNFCCC (2011b) Approaches to Address Loss and Damage Associated with Climate Change Impacts in Developing Countries that are Particularly Vulnerable to the Adverse Effects of Climate to Enhance Adaptive Capacity - Activities to be undertaken under the Work Programme, Subsidiary Body for Implementation (SBI) paper, FCCC/SBI/2011/L.35/ Add.1, UNFCCC, Bonn [online] http://unfccc.int/resource/docs/2011/sbi/eng/135a01.pdf (accessed 29 January 2013).

UNFCCC (2012a) UNFCCC Adaptation Private Sector Initiative (PSI) [online] http://unfccc.int/adaptation/nairobi_work_programme/private_sector_initiative/items/ 4623.php (accessed 26 March 2013).

UNFCCC (2012b) 'A literature review on the topics in the context of thematic area 2 of the work programme on loss and damage: a range of approaches to address loss and damage associated with the adverse effects of climate change', Subsidiary Body for Implementation (SBI) paper, FCCC/SBI/2012/INF.14, UNFCCC, Bonn [online] http://unfccc.int/resource/docs/2012/sbi/eng/inf14.pdf (accessed 23 January 2013).

UNFCCC (2012c) Current Knowledge on Relevant Methodologies and Data Requirements as well as Lessons Learned and Gaps Identified at Different Levels, in Assessing the Risk of Loss and Damage Associated with the Adverse Effects of Climate Change, Technical paper, FCCC/TP/2012/1, UNFCCC, Bonn [online] http://unfccc.int/resource/docs/2012/tp/01.pdf (accessed 23 January 2013).

UNFCCC (2013a) Decision -/CP.19 Warsaw International Mechanism for Loss and Damage Associated with Climate Change Impacts [online]

https://unfccc.int/files/meetings/warsaw_nov_2013/decisions/application/pdf/cop19_ lossanddamage.pdf (accessed 10 December 2013).

UNFCCC (2013b) Report of the Conference of the Parties on its Eighteenth Session, held in Doha from 26 November to 8 December 2012, Conference of the Parties decision paper FCCC/CP/2012/8/Add.1, UNFCCC, Bonn [online] http://unfccc.int/resource/docs/2012/cop18/eng/08a01.pdf (accessed on 26 March 2013).

UNFCCC (2013c) Private Sector Initiative - Database of Actions on Adaptation [online] $\mathrm{http} / /$ unfccc.int/adaptation/nairobi_work_programme/private_sector_initiative/items/ 6547.php (accessed 28th March 2013).

UNISDR (2011) Statement of Commitment by the Private Sector for Disaster Prevention, Resilience and Risk Reduction, International Strategy for Disaster Reduction [online] http://www.unisdr.org/files/19873_statementofcommitmentbytheprivatese.pdf (accessed 26 March 2013).

UNISDR (2013a) Disaster Risk Reduction Private Sector Partnerships (DRR-PSP) [online] http://www.preventionweb.net/english/professional/networks/public/psp/ (accessed 26 March 2013). 
UNISDR (2013b) Evidence, UNISDR Newsletter, February [online] http://www.preventionweb.net/files/31469_20130227evidence15.pdf (accessed 26 March 2013).

UNISDR (2013c) UNISDR private sector initiative launched in Africa, UNISDR News Archive [online] [online] http://www.unisdr.org/archive/31267 (accessed 26 March 2012).

United States of America (2011) 'Submission by the United States of America Work program on loss and damage associated with the adverse effects of climate change 25 February 2011' [online] http://unfccc.int/files/adaptation/cancun_adaptation_framework/application/pdf/ usa_25_february_2011.pdf (accessed 30 March 2013).

Verheyen, R. (2012) Loss \& Damage: Tackling Loss \& Damage - A New Role for the Climate Regime [online] http://www.loss-and-damage.net/download/6877.pdf (accessed 26 March 2013).

Warner, K. and van der Geest, K. (2013) 'Loss and damage from climate change: local-level evidence from nine vulnerable countries', International Journal of Global Warming, Vol. 5, No. 4, pp.367-386.

Warner, K., Zissener, M., Kreft, S., Höppe, P., Bals, C., Linnerooth-Bayer, J., Haas, A., Gurenko, E., Loster, T. and Burton, I. (2010) Solutions for Vulnerable Countries and People, Designing and Implementing Disaster Risk Reduction \& Insurance for Adaptation [online] An Munich Climate Insurance Initiative (MCII) Paper [online] http://www.ehs.unu.edu/file/get/5326 (accessed 28 March 2013).

World Bank (2012) The Little Data Book on Private Sector Development, The International Bank for Reconstruction and Development/The World Bank, Washington [online] http://data.worldbank.org/sites/default/files/little-data-book-on-private-sector-dvlpmnt2012.pdf (accessed 25 March 2013).

World Bank (2013) World Development Report 2013 Jobs, The International Bank for Reconstruction and Development/The World Bank, Washington [online] http://siteresources.worldbank.org/EXTNWDR2013/Resources/82580241320950747192/8260293-1322665883147/WDR_2013 Report.pdf (accessed 25 March 2013).

\section{Notes}

1 The stakeholders of private sector companies include the shareholders, customers, suppliers, employees and creditors as well as the government in a legislative and overseeing role-yet the impact that companies can have through their actions can be wider - affecting the general public, other businesses, communities, interest and trade groups, as well as other associated bodies.

2 See our working paper for a more detailed summary of the private sector references provided by submissions to the UNFCCC at:

http://www.lse.ac.uk/GranthamInstitute/publications/WorkingPapers/Papers/140-49/WP142Observations-of-private-sector-in-UNFCCCs-loss-and-damage-of-climate-changeprogramme.pdf.s 